\title{
Usage Pattern of Electronic Resources among the Research Scholars in Anna University of Technology, Coimbatore and Its Affiliated Colleges
}

\author{
Dr.L.Santhi ${ }^{1}$, Dr.N.Radhakrishnan ${ }^{2}$ \\ ${ }^{1}$ Librarian, PSGR Krishnammal College for Women, Coimbatore. \\ ${ }^{2}$ Associate Professor, Dept. of Library and Information Science, Periyar University, Salem.
}

\begin{abstract}
The main focus of the research was to examine the Usage pattern of electronic resources by the research scholars from Engineering Institutions affiliated to Anna University of Technology, Coimbatore. The study was carried out for researchers who are doing Ph.D in Anna University, Coimbatore and its affiliated institutions to explore their usage pattern of electronic resources. Questionnaire method was used to examine and collect data from the research scholars. The collected data has been analyzed with the help of Statistical Package for Social Science (SPSS). Statistical methods like percentage, Chi-Square and ANOVA were used. The Hypotheses framed were proved by this study. The results revealed that there is a significant difference among researchers in different age groups who are familiar with utilization of electronic resources. Course oriented web pages should be linked with library websites which in turn help the research scholars to use these resources easily and effectively.
\end{abstract}

Keywords: Electronic resources, Engineering College Libraries, Research Scholars, Print resources

\section{Introduction}

With the growing popularity of e-resources, the traditional libraries are gradually migrating from print documents to e-resources and providing access to information which is considered to be more important than the print medium. This has led academic environment to relook into their collection development and functioning. Application of Information Communication Technology (ICT) in libraries has provided enough opportunities for building e-resources and disseminated them in the manner which suits the needs of academics. To maximize the e-resources' use in these libraries, the attitudes of the users are to be measured to maximize the usage. Spending large amount on e-resources may not create an impact on the services until proper human resource is deployed to serve the end users. The assumption and facts are to be analyzed to study and find out the need of the users so as to support and provide an effective access to e-resources.

\section{Review of Literature}

Studies related to various electronic resources usage pattern of faculties and research scholars of various colleges and universities were undertaken by different authors. The studies by Ansari, Rekha Chirra,Madhusudhan and Amritpal Kaur revealed that electronic resources are the best means of getting current and up-to-date information. E-journals have become a vital part of information for research work. $100 \%$ of the respondents admit that e-resources can be good substitute for conventional resources if the access speed is fast. The information available in e-resources has been a great asset for the respondents. They have been able to keep themselves abreast of the latest information and improve their academic and professional competency.

Masoom Raza and Ashok Kumar Upadhyay revealed that the most common problem faced by the respondents is that there is difficulty in accessing full text and many of the respondents are not satisfied with the Internet facilities available. Some problems like lack of training and slow downloading have been found and the researchers felt the difference about the need for print journals as well as electronic journals.

It is clear from the above reviews that usage of electronic resources requires User education should be conducted for a small group of faculty members belonging to a single discipline such as mathematics, physics, chemistry, English at a time so that the resources accessible under the consortium in a particular subject can be made known to the faculty members concerned and is highly focused.

\section{Objectives}

The main objective of the study is to gain a clear insight into the impact of e-resources usage pattern among research scholars and to critically assess its implementation, and to assess the contemporary use of electronic information resources by the research scholars. 


\section{Hypothesis}

The following Hypothesis was framed in this connection. (1) There is a significant difference on the usage pattern of print and e-resources among research scholars. (2) Age of the research scholars is the influencing factor in terms of e-resource usage pattern among the respondents.

\section{Methodology}

The researcher used a design of empirical survey. This study involves both primary, secondary data and wide interaction with a sample group. Simple random sampling method is chosen as far as primary data is concerned.

The population size of the present study includes 160 colleges. There were 781 research scholars who had registered for doing Ph.D in different disciplines in the year 2007-08. Out of a total population (781), 610 respondents were randomly served the questionnaire for the present study. 499 respondents had given their feed back at the response rate of $81.80 \%$.

\section{Analysis}

Utilization of e-resources is analyzed in terms of the location to access, format preferences, sources for locating the e-information, are presented in the following Tables.

Table.1 Classification by utilization of e-resources with location and preferred format

\begin{tabular}{|c|c|c|c|c|}
\hline \multirow{2}{*}{ S.No } & \multirow{2}{*}{ Variable } & \multicolumn{3}{|c|}{ Response } \\
\hline & & Frequency & Percentage & Total \\
\hline 1 & \multicolumn{4}{|c|}{ Location to access E- Resources } \\
\hline 1.1 & On campus & 104 & 20.84 & \multirow{3}{*}{$499(100)$} \\
\hline 1.2 & Off campus & 26 & 5.21 & \\
\hline 1.3 & Both & 369 & 73.95 & \\
\hline 2 & \multicolumn{4}{|c|}{ Preferred format } \\
\hline 2.1 & Print & 131 & 26.25 & \multirow{3}{*}{$499(100)$} \\
\hline 2.2 & Electronic & 45 & 9.02 & \\
\hline 2.3 & Both & 323 & 64.73 & \\
\hline
\end{tabular}

$104(20.84 \%)$ respondents are using the e-resources at their campus, and $26(5.21 \%)$ research scholars replied that they are using e-resources outside campus like computer centers, and home. Majority of the respondents $369(73.95 \%)$ access e-resources both on campus and off campus location.

$131(26.25 \%)$ respondents prefer to use print formats when they access the e-resources, $45(9.02 \%)$ of them prefer to use electronic formats and $323(64.73 \%)$ respondents browse both print as well as electronic formats.

Table.2 Classification by utilization of e-resources with types of e-resources, method of access, purpose and locating the information

\begin{tabular}{|c|c|c|c|c|}
\hline \multirow{2}{*}{ S.No } & \multirow{2}{*}{ Variable } & \multicolumn{3}{|c|}{ No. of Respondents } \\
\hline & & Yes $(\%)$ & No (\%) & Total (\%) \\
\hline 1 & \multicolumn{4}{|l|}{ Types of e-resources } \\
\hline 1.1 & E-Books & $432(86.6)$ & $67(13.4)$ & \multirow{7}{*}{499 (100) } \\
\hline 1.2 & E-Journals & $488(97.8)$ & $11(2.2)$ & \\
\hline 1.3 & E-Dictionaries & $162(32.5)$ & $337(67.5)$ & \\
\hline 1.4 & E-Theses & $228(45.7)$ & $271(54.3)$ & \\
\hline 1.5 & E-Magazines & $278(55.7)$ & $221(44.3)$ & \\
\hline 1.6 & E-Catalogs & $78(15.6)$ & $421(84.4)$ & \\
\hline 1.7 & E-Databases & $261(52.3)$ & $238(47.7)$ & \\
\hline 2 & \multicolumn{4}{|l|}{ Method of information access } \\
\hline 2.1 & Download and copy on $\mathrm{CD} /$ pendrive & $335(67.1)$ & $164(32.9)$ & $499(100)$ \\
\hline 2.2 & Take print out & $397(79.6)$ & $102(20.4)$ & \\
\hline 2.3 & Only reading & $86(17.2)$ & $413(82.8)$ & \\
\hline 3 & \multicolumn{4}{|l|}{ Purpose of using e- resources } \\
\hline 3.1 & To update for research work & $489(98)$ & $10(2)$ & \multirow{3}{*}{499 (100) } \\
\hline 3.2 & For preparing academic course work & $323(64.7)$ & $176(35.3)$ & \\
\hline 3.3 & To publish articles / Papers & $322(64.5)$ & $177(35.5)$ & \\
\hline 4 & \multicolumn{4}{|c|}{ Types of Sources used for locating information } \\
\hline
\end{tabular}


Usage Pattern of Electronic Resources among the Research Scholars in Anna University of

\begin{tabular}{|c|c|c|c|c|}
\hline 4.1 & Databases & $353(70.7)$ & $146(29.3)$ & \multirow{7}{*}{$499(100)$} \\
\hline 4.2 & Directories & $126(25.3)$ & $373(74.7)$ & \\
\hline 4.3 & Indexes / Abstracts & $175(35.1)$ & $324(64.9)$ & \\
\hline 4.4 & Bibliographies & $124(24.8)$ & $375(75.2)$ & \\
\hline 4.5 & Union Catalogue & $44(8.8)$ & $455(91.2)$ & \\
\hline 4.6 & Web online public access catalogue & $98(19.6)$ & $401(80.4)$ & \\
\hline 4.7 & Search engines / Meta search engines & $421(84.4)$ & $78(15.6)$ & \\
\hline
\end{tabular}

It is observed that $432(86.6 \%)$ research scholars are using e-books for their research. Majority (98\%) of the respondents use e-journals for their research, 162 (32.5\%) browse e-dictionaries for their research, 228 $(45.7 \%)$ research scholars are using e-theses for their research, 278 (55.7\%) research scholars are using e-magazines for their research,78 (15.6\%) browse e-catalogs for their research, $261(52.3 \%)$ research scholars are using e-databases for their research.

\section{Hypothesis testing}

\section{Gender and Usage Pattern of E-Resources}

The e-resources are used by the researchers for a number of days or only for instant access. Because of this usage pattern, the output of e-materials used by them are sometimes hard copy or soft copy. Hence the researcher is interested in knowing the classification of e-resources that are used in printout form and soft form.

The analysis of association between gender and usage pattern tested with print, electronic and both format has been made using chi-square test and the results are summarized in the following tables.

Table.3 Association between gender and usage pattern of print and e-resources

\begin{tabular}{|c|l|c|c|c|c|}
\hline \multirow{2}{*}{ S.No } & \multirow{2}{*}{ Gender } & \multicolumn{3}{|c|}{ Usage pattern } & \multirow{2}{*}{$\chi^{\mathbf{2}}(\mathbf{d f} ; \mathbf{p}(\mathbf{s}))$} \\
\cline { 3 - 5 } & & Print & E-resource & Both & \\
\hline 1 & Male & 83 & 34 & 212 & \multirow{2}{*}{$2.254(2 ; 0.324)$} \\
\hline 2 & Female & 48 & 11 & 111 & \\
\hline
\end{tabular}

The analysis pertained to access the e-resources among the respondents showed that the chi square test results i.e. chi $^{\wedge} 2=2.254$ at 2 degrees of freedom with the probability value of 0.324 which is greater than $5 \%$ level and hence it is inferred that there is no significant difference among research scholars for accessing e-resources.

Table.4 Association between research scholars pertinent to usage pattern of print and e-resources

\begin{tabular}{|c|l|c|c|c|c|c|c|c|}
\hline \multirow{2}{*}{ S. No } & \multirow{2}{*}{ E-resources } & \multicolumn{2}{|c|}{ Print } & \multicolumn{2}{c|}{ Electronics } & \multicolumn{2}{|c|}{ Both } & \multirow{2}{*}{$\chi^{\mathbf{2}}(\mathbf{d f} ; \mathbf{p}(\mathbf{s}))$} \\
\cline { 3 - 9 } & & Yes & No & Yes & No & Yes & No & \\
\hline 1 & E- Books & 21.2 & 5.0 & 7.0 & 2.0 & 58.5 & 6.2 & $11.261(4 ; 0.024)$ \\
\hline 2 & E- Journals & 25.7 & 0.6 & 8.6 & 0.4 & 63.7 & 1.0 & $1.761(2 ; 0.415)$ \\
\hline 3 & E- Dictionaries & 4.0 & 22.2 & 3.4 & 5.6 & 25.1 & 39.7 & $23.977(2 ; 0.000)$ \\
\hline 4 & E- Theses & 7.2 & 19 & 5.2 & 3.8 & 33.3 & 31.5 & $25.187(4 ; 000)$ \\
\hline 5 & E-Magazines & 9.4 & 16.8 & 5.6 & 3.4 & 40.7 & 24 & $28.326(2 ; 000)$ \\
\hline 6 & E- Catalogs & 1.4 & 24.8 & 1.2 & 7.8 & 13 & 51.7 & $15.637(2 ; 000)$ \\
\hline 7 & E- Databases & 9.0 & 17.2 & 3.4 & 5.6 & 39.9 & 24.8 & $31.944(2 ; 000)$ \\
\hline
\end{tabular}

The probability values are significant at $5 \%$ level of significance, it is concluded that there is a significant difference among research scholars related to usage pattern for other e-resources such as e-book, e-dictionaries, e-theses, e- magazines, e-catalogs and e-databases.

Table.5 Association between age groups and utilization of e- resources

\begin{tabular}{|c|c|c|c|c|c|c|c|c|c|c|c|c|c|}
\hline \multirow[t]{2}{*}{ E-resources } & \multicolumn{2}{|c|}{$\begin{array}{c}\text { Age group } \\
23-27 \\
\text { Opinion }\end{array}$} & \multicolumn{2}{|c|}{$\begin{array}{c}\text { Age group } \\
28-32 \\
\text { opinion }\end{array}$} & \multicolumn{2}{|c|}{$\begin{array}{c}\text { Age group } \\
\mathbf{3 3 - 3 7} \\
\text { opinion }\end{array}$} & \multicolumn{2}{|c|}{$\begin{array}{l}\text { Age group } \\
38-42 \\
\text { opinion }\end{array}$} & \multicolumn{2}{|c|}{$\begin{array}{c}\text { Age group } \\
43-47 \\
\text { opinion }\end{array}$} & \multicolumn{2}{|c|}{48 and above } & \multirow[t]{2}{*}{$\chi^{2}(\mathrm{df} ; \mathrm{p}(\mathrm{s}))$} \\
\hline & Yes & No & Yes & No & Yes & No & Yes & No & Yes & No & Yes & No & \\
\hline E-Book & 16.2 & 3 & 41.5 & 5.6 & 23.2 & 3.8 & 4.4 & 1.0 & 1.0 & - & 0.2 & - & $2.443(5 ; .0 .785)$ \\
\hline E-Journals & 19.2 & - & 45.5 & 1.6 & 27.1 & - & 5.0 & 0.4 & 1.0 & - & 0.2 & - & $11.207(5 ; 0.047)$ \\
\hline E-Dictionaries & 6.2 & 13 & 13.8 & 33.3 & 9.6 & 17.4 & 1.8 & 3.6 & 0.8 & 0.2 & 0.2 & - & $8.864(5 ; .0 .115)$ \\
\hline E-Theses & 5.6 & 13.6 & 23.8 & 23.2 & 12.4 & 14.6 & 3.2 & 2.2 & 0.6 & 0.4 & 0.2 & - & $16.470(5 ; 0.006)$ \\
\hline E-Magazines & 9.6 & 9.6 & 24.2 & 22.8 & 17.2 & 9.8 & 3.8 & 1.6 & 0.6 & 0.4 & 0.2 & - & $9.646(5 ; 0.086)$ \\
\hline E-Catalogs & 2.6 & 16.6 & 6.2 & 40.9 & 5.0 & 22 & 1.4 & 4.0 & 0.2 & 0.8 & 0.2 & - & $9.871(5 ; 0.079)$ \\
\hline E-Databases & 10.4 & 8.8 & 23.8 & 23.2 & 14.6 & 12.4 & 2.8 & 2.6 & 0.4 & 0.6 & 0.2 & - & $1.782(5 ; 0.878)$ \\
\hline
\end{tabular}


The analysis of use behavior of electronic resources towards the different age groups among the respondents showed that the probability value are $0.785,0.115,0.086,0.079$ and 0.878 which are greater than the level of significance at $5 \%$ level. Hence e-books, e-dictionaries, e-magazines, e-catalogs and e-databases show that there is no significant difference among the different age group of research scholars.

\section{Conclusion}

It is clear from the study shows that research scholars prefer electronic resources as a greater part for their research. So it is essential to develop specific web pages, blogs and wikis accommodating the topic in conjunction with navigation facilities to all subscribed online databases, e-journals, and open access e-information resources. These course oriented should be linked with library websites which in turn help the research scholars to use these resources easily and effectively. Libraries should take active participation in various e-journal consortiums for maximizing procurement of e-journals at minimal cost on sharing basis by which institutes can afford to balance e-subscriptions.

\section{References}

[1]. Abdul Mannan Khan and Naved Ahmad (2009), "Use of e-journals by research scholars at Aligarh Muslim University and Banaras Hindu University", The Electronic Library, Vol. 27, No. 4, pp.708-717.

[2]. Agboola I.O. (2010), "Use of print and electronic resources by agricultural science students in Nigerian universities", Library and Information Science Research, Vol.32, No.1, pp.62-65.

[3]. Amritpal Kaur (2006), "Use of e-resources by teachers and researchers of the science and Engineering \& Technology faculties in Guru Nanak Dev University: A survey”, proceeding of the National Convention on Knowledge, Library and Information Networking (NACLIN 2006), University of Jammu, Jammu, pp. 267-285.

[4]. Ansari M.N. (2010), "Use of Electronic Resources among academics at the University of Karachi” Library Philosophy and practice, ISSN: $1522-0222$.

[5]. Asemi A. and Riyahiniya N. (2007), "Awareness and use of digital resources in the libraries of Isfahan University of medical sciences, Iran", The Electronic Library, Vol.25, No.3, pp.316-327.

[6]. BajpaiR.P.,BidyutMalK.and Geetanjali Bajpai(2009),"Use of e-resources through consortia:A boon to users of Indian university libraries" International conference on academic libraries, 5-8th oct, New Delhi, India, pp.500-503.

[7]. Baljinder Kaur and Rama Verma (2006), "Use of electronic resources at TIET library Patiala: a case study", ILA Bulletin, Vol.42, No.3, pp.18-20.

[8]. Baljinder Kaur and Rama Verma (2009), "Use of electronic information resources: A case study of Thapar University", DESIDOC Journal of Library and Information Technology, Vol.29, No.2,pp.67-73.

[9]. Borrego A., Anglada L., Barrios M. and Comellas N. (2007) "Use and Users of Electronic Journals at Catalan Universities: The Results of a Survey", The Journal of Academic Librarianship, Vol.33, No.1, pp.67-75.

[10]. Chandel A.S., Mezbah-UI-Islam M. and Sudhir G. (2003), "Use of resources by research scholars in university libraries with special reference to electronic media", International CALIBER 2003, Ahmedabad.

[11]. Hewitson A. (2002), "Use and awareness of electronic information services by academic staff at Leads metropolitan University: a qualitative study", Journal of Librarianship and Information Science, Vol.34, No.1, pp.34-52.

[12]. Ibrahim A.E.(2004), "Use and user perception of electronic resources in the United Arab Emirates University (UAEU)", Libri, Vol.54, No.1, pp.18-29.

[13]. Kumar B.D., Vatnal R.M., Gururaj Hadagali S. and Lata Patil (2006), "Use of UGC-INFONET consortium by the Faculty members and research scholars of department of Chemistry, Karnatak University, Dharwad: A Study", 4th International Convention CALIBER-2006, Gulbarga, pp. 257-263.

[14]. Masoom Raza M. and Ashok Kumar Upadhyay (2006), "Usage of E-journals by researchers in Aligarh Muslim University: A study", The International Information and Library Review, Vol.38, No.3, pp.170-179.

[15]. Natarajan K., Suresh B., Sivaraman P. and Sevukan R. (2010), "Use and User perception of electronic resources in Annamalai University: A case study", Annals of Library and Information Studies, Vol.57, pp.59-64.

[16]. Naushad Ali (2005), "The use of electronic resources at IIT Delhi Library: a study of search behaviours", The electronic library, Vol.23, No.6, pp.691-700. 